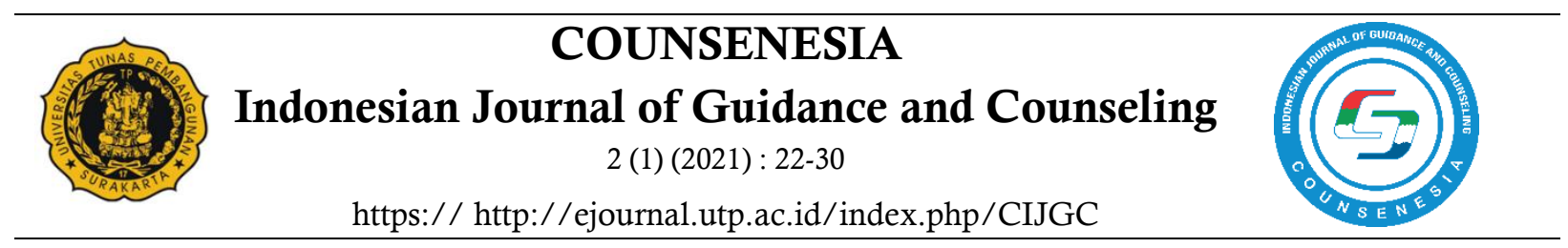

\title{
EFEKTIVITAS KONSELING KELOMPOK ONLINE PENDEKATAN BEHAVIOR TEKNIK SELF MANAGEMENT UNTUK MENGURANGI KECENDERUNGAN KECANDUAN GAME ONLINE SISWA
}

\author{
Ridho Muhammad Reza', Mulawarman Mulawarman² \\ 1,2 Universitas Negeri Semarang \\ Email: ridhomreza@gmail.com
}

\begin{abstract}
Info Artikel
Abstrak

Riwayat Artikel

Tujuan penelitian ini yaitu untuk mengetahui keefektifan konseling kelompok online Diterima:

25 Maret 2021

Disetujui: pendekatan behavior teknik self management untuk mengurangi kecenderungan kecanduan game online. Jenis penelitian ini merupakan penelitian eksperimen dengan desain one group 19 April 2021 Publikasi: pretest-posttest. Teknik pengambilan subjek penelitian menggunakan purposive sampling sejumlah 6 siswa. Alat pengumpul data yang digunakan adalah Gaming Addiction Scale (GAS) oleh Lemmens dkk (2009) sebanyak 7 indikator dan 21 item. Validitas diuji dengan rumus Product moment dan dengan koefesien reliabilitas 0,924 . Teknik analisis data yang digunakan analisis deskripstif dan analisis uji Wilcoxon. Berdasarkan hasil uji uji Wilcoxon $(\mathrm{Z}=-2,201$, $\mathrm{p} \leq 0,05$ ) hal ini menunjukkan bahwa konseling kelompok online pendekatan bevavior teknik self management terbukti efektif untuk mengurangi kecenderungan kecanduan game online pada siswa. Selanjutnya, konselor sekolah dapat menerapkan dan mengembangkan konseling kelompok online pendekatan bevavior teknik self management sebagai salah satu strategi alternatif untuk mengurangi kecenderungan kecanduan game online siswa.
\end{abstract}

Kata Kunci: konseling kelompok online; pendekatan behavior; teknik self management; game online

\begin{abstract}
This study aims to find out the effectiveness of online group counselling approach behaviour self-management techniques to reduce the tendency of online gaming addiction. This type of research is an experimental study with the design of one group pretest-posttest. The study subject retrieval technique uses a purposive sampling of 6 students. The data collection tool used is the Gaming Addiction Scale (GAS) by Lemmens et al. (2009) as many as 7 indicators and 21 items. Validity is tested with the Product moment formula and with a reliability coefficient of 0.924 . Based on Wilcoxon test results $(Z=-2,201, p \leq 0.05)$, the online group counselling approach behaviour self-management techniques proved effective to reduce online gaming addiction in students. Furthermore, school counsellors can implement and develop online group counselling approaches behaviour self-management techniques as one of the alternative strategies to reduce online gaming addiction students' tendency.
\end{abstract}

Keywords: online group counseling; behavior approach; self management technique; online gaming

(C) 2021 Universitas Tunas Pembangun Surakarta

ISSN: 2746-3532 (Online) 


\section{PENDAHULUAN}

Pada era globalisasi ini, ilmu pengetahuan dan teknologi seakan tidak akan pernah berhenti untuk menghasilkan produk-produk teknologi yang tidak terhitung nilainya. Semakin modernnya zaman, maka akan semakin canggih pula teknologinya. Teknologi memberikan manfaat dan kemudahan bagi setiap individu dalam berbagai aspek kehidupan, tak terkecuali untuk hiburan. Game online merupakan salah satu produk teknologi yang memiliki manfaat sebagai sebuah hiburan. Melansir dari Tech Crunch (2020), perusahaan Verizon menyatakan bahwa persentase pengguna game online selama pandemi Covid-19 mengalami peningkatan yang signifikan. Verizon mencatat pengguna video game meningkat 75 persen selama jam sibuk. Plat distribusi game steam mencatat rekor pengguna game dengan lebih dari 20 juta pengguna pada 16 Maret 2020. Hal ini menunjukkan bahwa game online berperan penting sebagai hiburan bagi manusia.

Menurut Young (2009), Game online merupakan situs yang menyediakan berbagai jenis permainan yang dapat melibatkan beberapa pengguna internet di berbagai tempat yang berbeda untuk saling terhubung di waktu yang sama dengan melalui jaringan komunikasi online. Game online pada dasarnya ditujukan untuk mengusir kepenatan atau sekedar melakukan refreshing otak setelah melakukan aktivitas sehari-hari. Bagi remaja, bermain merupakan kebutuhan sekunder yang sebaiknya terpenuhi karena dapat memberikan kesegaran baik secara fisik maupun psikis, sehingga terlepas dari rasa lelah dan bosan serta memperoleh semangat yang baru (Nakita dalam Gaol, 2012). Selain itu, remaja biasanya mengikuti berbagai perkembangan zaman dan mudah terpengaruh oleh gaya hidup di sekitarnya (Habsy, 2017). Bagi para remaja, game online banyak sekali diminati, seakan-akan game online menjadi tren (gaya hidup) mereka. Keingintahuan yang tinggi, menjadikan para remaja terus mencoba berbagai fitur smartphone yang ada, sehingga penggunaan smartphone semakin meningkat. Pemanfaatan game online secara tepat dapat memberikan dampak positif bagi remaja. Studi terdahulu oleh Granic, Lobel, \& Engels (2014) menunjukkan bahwa bermain game menumbuhkan banyak keterampilan kognitif, motivasi dan skill sosial.

Namun pada kenyataannya, game online justru banyak membuat individu khususnya remaja menjadi kecanduan. Permainan game online memiliki sifat adiktif atau membawa candu (Ariantoro, 2016). Menurut Kartini (2016), semakin tinggi intensitas bermain game online maka semakin tinggi intensi berperilaku agresif orang tersebut. Individu dengan intensitas bermain game yang tinggi menjadi memiliki interaksi yang bersifat disosiatif, yakni menghasilkan hubungan dalam bentuk persaingan (competion), kontravesi (contravention), dan pertikaian (conflict) dalam kehidupan sosialnya (Kusumawardani, 2015). Menurut Lemmens, Valkenburg, \& Peter (2009) seseorang yang mengalami kecanduan memiliki aspek-aspek berupa salience (berpikir tentang bermain game online sepanjang hari), tolerance (waktu bermain game online yang semakin meningkat), mood modification (bermain game online untuk melarikan diri dari masalah), relapse (kecendrungan untuk bermain game online kembali setelah lama tidak bermain), withdrawal (merasa buruk jika tidak dapat bermain game online), conflict (bertengkar dengan orang lain karena bermain game online secara berlebihan), dan problems (mengabaikan kegiatan lainnya sehingga menyebabkan permasalahan).

Sebuah studi menunjukkan bahwa kecanduan game online lebih sering terjadi pada remaja (Brand, Todhunter, \& Jervis, 2017). Menurut Rudhiati, Apriany, \& Hardianti (2015), remaja menghabiskan waktu saat bermain game lebih dari dua jam/hari, atau lebih dari $14 \mathrm{jam} /$ minggu. Ditambah dengan adanya pandemi covid 19 yang terjadi di Indonesia sehingga terjadi peningkatan kecenderungan game online pada remaja (Nugraha, Awalya, 
\& Mulawarman, 2021). Data tersebut dikuatkan oleh peneliti di kota Semarang khususnya SMA Kesatrian 1 Semarang dilakukan dengan membagikan kuisioner skala kecanduan game online yang melibatkan 152 siswa kelas XI dengan hasil bahwa bahwa $66 \%$ dari responden tersebut adalah pemain aktif game online. Jumlah siswa yang memiliki kecenderungan game online yang tinggi terdapat 41 anak, 95 siswa dalam kategori sedang dan 16 siswa dalam kategori rendah. Berdasarkan data tersebut, dengan banyaknya siswa yang memiliki kecenderungan kecanduan game online yang tinggi, perlu adanya strategi bantuan pada siswa untuk mengurangi kecenderungan kecanduan game online siswa supaya berkurang secara efektif.

Adapun layanan yang digunakan dalam penelitian ini adalah layanan dalam format kelompok, yaitu konseling kelompok. Konseling kelompok menurut Wibowo (2015) layanan konseling kelompok adalah suatu proses interpersonal yang dinamis yang menitik beratkan pada kesadaran berpikir dan tingkah laku, melibatkan fungsi terapeutis, berorientasi pada kenyataan, ada rasa saling percaya mempercayai, ada pengertian, penerimaan dan bantuan.

Dengan adanya kondisi covid-19 di Indonesia, maka pelaksanaan konseling kelompok akan dilakukan secara online. Menurut Amani (2007) e-Counseling adalah adalah konseling yang dilakukan melalui internet yang secara umum merujuk pada profesi yang berkaitan dengan layanan kesehatan mental melalui teknologi komunikasi internet. Dengan menggunakan konseling online, diharapkan dapat memberikan layanan yang mudah kepada anggota kelompok karena tidak terbatas ruang dan waktu.

Salah satu pendekatan dalam konseling yaitu pendekatan behavior. Pendekatan behavior adalah suatu pandangan ilmiah tentang tingkah laku manusia. Menurut Corey (2005) terapi behavior diarahkan pada tujuan untuk memperoleh tingkah laku baru dan penghapusan tingkah laku yang maladaptif. Perubahan perilaku harus diusahakan melalui proses belajar (learning) atau belajar kembali (relearning) yang berlangsung selama proses konseling. Proses konseling pada dasarnya juga dipandang sebagai proses belajar yang dimaksudkan belajar untuk bertingkah laku kearah yang lebih baik dengan bantuan konselor kemudian pada akhirnya klien dapat terbiasa dengan berperilaku yang adaptif meskipun tanpa dibimbing konselor terus-menerus (Winkel \& Hastuti, 2006). Dalam pandangan behavior, tingkah laku bermasalah dalam pendekatan behavior terdiri dari dua macam, yaitu tingkah laku yang berlebih (excessive) dan tingkah laku yang kurang (deficit) (Komalasari, 2016). Karena kecenderungan kecanduan game online merupakan tingkah laku yang berlebih (excessive) serta berkaitan langsung dengan disiplin diri, maka pendekatan ini dapat dilakukan secara lebih mendalam kepada individu yang bersangkutan. Konseling kelompok behavioral sangat menitikberatkan kepada pengubahan tingkah laku dan tindakan, tidak terkecuali dalam sebuah kelompok. Konselor dapat menjadi pembimbing tiba-tiba kemudian bisa pula menjadi fasilitator atau juga supervisor dalam sesi-sesi konseling yang dilakukan (Erdiyati, 2018).

Penerapan konseling kelompok behavioral ini dilaksanakan dengan teknik yang berakar pada teori pengkondisian operan B.F. Skinner yaitu "self management". Teknik self management sangat tepat digunakan dalam menangani permasalahan kecenderungan kecanduan game online. Menurut Komalasari dkk (2011), strategi self management (pengelolaan diri) adalah prosedur pengaturan perilaku oleh individu sendiri. Selain itu Teknik self management merupakan salah satu teknik konseling yang menggunakan pendekatan behavior dalam pelaksanaannya. Pada strategi ini, individu terlibat pada beberapa atau keseluruhan komponen dasar yakni menentukan perilaku sasaran, memonitor perilaku tersebut, memilih prosedur yang akan diterapkan, melaksanakan 
prosedur tersebut, dan mengevaluasi efektifitas prosedur tersebut. Self management meliputi pemantauan diri (self monitoring), reinforcement yang positif (self reward), kontrak atau perjanjian dengan diri sendiri (self contracting), dan penguasaan terhadap ransangan (stimulus control).

Berdasarkan penjelasan tersebut konseling kelompok online pendekatan behavior teknik self management dapat menjadi alternatif dalam upaya mengurangi kecenderungan kecanduan game online yang dialami oleh siswa sekolah menengah atas. Penggunaan teknik self-management pada masalah kecenderungan kecanduan game online bisa menjadi efektif karena kelebihan dari teknik ini yaitu dapat meningkatkan pengamatan seseorang dalam mengontrol lingkungannya serta dapat menurunkan ketergantungan seseorang pada konselor atau orang lain, pendekatan yang murah dan praktis, mudah digunakan, dan menambah proses belajar secara umum dalam berhubungan dengan lingkungan baik pada situasi bermasalah atau tidak (Cormier dalam Isnaini \& Taufik, 2015).

Hal ini didukung dengan penelitian terdahulu mengenai pemanfaatan layanan konseling kelompok. Ardani, Erwin, \& Halik (2019) dalam penelitiannya menunjukkan bahwa konseling kelompok dengan teknik self management dapat mereduksi perilaku membolos siswa. Penelitian tersebut dapat menyimpulkan bahwa terdapat penurunan perilaku membolos yang tidak signifikan jika tidak memberikan teknik self management terhadap siswa, sedangkan siswa yang diberikan perlakuan konseling kelompok dengan teknik self management terdapat hasil penurunan yang signifikan. Dengan demikian maka konseling kelompok dengan teknik self management efektif untuk mereduksi perilaku membolos terhadap siswa.

Berdasarkan latar belakang tersebut, maka tujuan penelitian adalah untuk menguji apakah konseling kelompok online pendekatan behavior teknik self management efektif dalam mengurangi kecenderungan kecanduan game online pada siswa kelas XI di SMA Kesatrian 1 Semarang.

\section{METODE}

Metode yang digunakan pada penelitian ini adalah eksperimen dengan jenis penelitian pre experimental design model one group pre-test and post-test design, dimana dalam rancangan ini hanya ada satu kelompok subyek yaitu kelompok eksperimen sebagai kelompok yang dikenakan perlakuan. Lalu dikenakan perlakuan berupa konseling kelompok online pendekatan behavior teknik self management dalam waktu 6 pertemuan, kemudian dilakukan pengukuran untuk kedua kalinya yang bertujuan agar mengetahui perbedaan hasil pre test sebelum diberikan perlakuan dengan post test setelah diberikan perlakuan.

Subjek dalam penelitian ini diambil bagian dari populasi yaitu siswa kelas XI SMA Kesatrian 1 Semarang yang berjumlah 152 siswa dari lima kelas. Peneliti mengambil 6 siswa kelas XI SMA Kesatrian 1 Semarang terpilih yang memiliki tingkat kecenderungan kecanduan game online paling tinggi (dari data awal) untuk melaksanakan pretest sebagai subjek penelitian atau responden konseling kelompok online pendekatan behavior teknik self management. Penelitian ini menggunakan sampel sumber data terpilih, yaitu dengan teknik purposive sampling. Peneliti akan melaksanakan konseling kelompok online pendekatan behavior ini selama 6 pertemuan dengan waktu 30-45 menit setiap sesi. Intrumen dalam penelitian ini menggunakan adaptasi dari game addiction scale (GAS) oleh Lemmens, Valkenburg, \& Peter (2009). Game Addiction Scale (GAS) terdiri dari total 21 butir pernyataan dengan masing-masing aspek tiga pernyataan (saliance, 
tolerance, mood modification, relapse, withdrawal, conflict dan problems) dengan beragam pertanyaan (contohnya "Apakah Anda berpikir untuk bermain game sepanjang hari?"). Instrumen ini terdiri atas lima tingkatan jawaban, yaitu tidak pernah (1), jarang (2), kadang-kadang (3) sering (4), dan selalu (5). Langkah-langkah yang dilakukan dalam penelitian ini guna mengadaptasi instrument tersebut adalah melakukan backtranslation instrumen, melakukan validitas instrument kepada dosen validator, dilanjutkan merevisi butir-butir dalam instrumen yang disesuaikan sehingga instrumen jadi dan siap untuk digunakan dalam penelitian. Pengujian validitas skala kecenderungan kecanduan game online dilakukan dengan menggunakan uji product moment dengan hasil seluruh 21 butir pertanyaan dinyatakan valid, kemudian reliabilitas instrumen ditentukan dengan uji alpha cronbach dengan hasil 0,924 yaitu sangat reliabel. Uji hipotesis dilakukan dengan mengguakan analisis data deskriptif dan analisis inferensial uji wilcoxon.

\section{HASIL DAN PEMBAHASAN}

Gambaran tingkat kecenderungan kecanduan game online siswa kelas XI di SMA Kesatrian 1 Semarang sebelum diberikan konseling kelompok online pendekatan behavior teknik self management dari keenam siswa berada pada kategori tinggi. Berikut disajikan hasil pretest dan posttest 6 siswa yang menjadi anggota konseling kelompok:

Tabel 1. Hasil Pre-test dan Post-test Skala Kecenderungan Kecanduan Game Online

\begin{tabular}{llllllllll}
\hline \multirow{2}{*}{ No } & \multirow{2}{*}{ Nama } & \multicolumn{3}{c}{ Pretest } & \multicolumn{3}{c}{ Posttest } & \multicolumn{2}{c}{ Penurunan } \\
\cline { 3 - 8 } 1 & FAAC & M & SD & Kriteria & M & SD & Kriteria & M & SD \\
\cline { 2 - 9 } 2 & HEE & 4,0 & 1,1 & Tinggi & 2,8 & 0,9 & Sedang & 1,3 & 0,2 \\
3 & RAS & 3,9 & 1,0 & Tinggi & 2,2 & 0,9 & Rendah & 1,8 & 0,1 \\
4 & NSS & 3,7 & 1,3 & Tinggi & 2,0 & 0.8 & Rendah & 1,9 & 0,2 \\
5 & SFS & 3,6 & 1,0 & Tinggi & 2,5 & 1,2 & Rendah & 1,2 & 0,1 \\
6 & FAF & 3,4 & 1,2 & Tinggi & 2,1 & 0,8 & Rendah & 1,5 & 0,2 \\
\hline \multicolumn{2}{l}{ Total } & 3,7 & 1,1 & Tinggi & 2,6 & 1,0 & Sedang & 0,8 & 0,2 \\
\hline
\end{tabular}

Keenam siswa tersebut sebelum diberikan treatment tergolong dalam kecenderungan kecanduan game online kategori tinggi dengan skor total rata-rata dari 6 orang siswa tersebut yaitu sebesar 3,7 dengan SD 1,1 yang termasuk dalam kriteria tinggi. Berikut disajikan rata-rata kecenderungan kecanduan game online siswa berdasarkan indikator adalah sebagai berikut:

Tabel 2. Hasil Pretest dan Posttest Skala kecenderungan kecanduan game online Per Indikator

\begin{tabular}{lccccccc}
\hline \multirow{2}{*}{ No } & \multirow{2}{*}{ Indikator } & \multicolumn{3}{c}{ Pre-Test } & \multicolumn{3}{c}{ Post-test } \\
\cline { 2 - 7 } & & Mean & SD & Kriteria & Mean & SD & Kriteria \\
\hline 1 & Salience & 4.3 & 0.8 & $\mathrm{ST}$ & 2.2 & 0.6 & $\mathrm{R}$ \\
2 & Tolerance & 3.6 & 1.3 & $\mathrm{~T}$ & 2.2 & 0.8 & $\mathrm{R}$ \\
3 & Mood Modification & 3.2 & 1.1 & $\mathrm{~S}$ & 2.6 & 0.8 & $\mathrm{R}$ \\
4 & Releapse & 3.4 & 0.6 & $\mathrm{~T}$ & 2.3 & 0.8 & $\mathrm{R}$ \\
5 & Withdrawal & 4.3 & 0.3 & $\mathrm{ST}$ & 1.5 & 0.5 & $\mathrm{R}$ \\
6 & Conflict & 4.1 & 0.7 & $\mathrm{~T}$ & 1.8 & 0.6 & $\mathrm{R}$ \\
7 & Problems & 3.9 & 1.2 & $\mathrm{~T}$ & 2.1 & 0.7 & $\mathrm{~S}$ \\
& Rata-Rata & 3.8 & 1.1 & Tinggi & 2.3 & 0.9 & Rendah \\
\hline
\end{tabular}

Hasil pre-test berdasarkan indikator perilaku kecenderungan kecanduan game online dari keenam konseli sebelum diberikan konseling kelompok online pendekatan behavior teknik self management, dapat dilihat pada tabel 2 bahwa yang menunjukkan 
nilai total rata-rata tertinggi yaitu salience dan withdrawal, serta yang menunjukkan nilai total rata-rata terendah adalah mood mofidication.

Setelah dilaksanakan treatment berupa layanan konseling kelompok online pendekatan behavior teknik self management sebanyak enam kali pertemuan, selanjutnya dilakukan post-test untuk mengetahui ada atau tidaknya penurunan tingkat kecenderungan kecanduan game online pada siswa kelas XI. Berdasarkan hasil post-test pada tabel 1 dapat diketahui bahwa dari 6 siswa yang telah mengikuti konseling kelompok online pendekatan behavior teknik self management diperoleh jumlah skor rata-rata sebesar 2,3 dan SD sebesar 0,9. Skor rata-rata yang diperoleh termasuk dalam kategori kecenderungan kecanduan game online rendah.

Hasil post-test berdasarkan setiap indikator perilaku kecenderungan kecanduan game online setelah diberikan perlakuan konseling kelompok online pendekatan behavior teknik self management pada tabel 2 menunjukkan bahwa indikator yang menunjukkan nilai total rata-rata tertinggi yaitu problems, sedangkan indikator yang menunjukkan nilai total rata-rata terendah yaitu mood modification dan withdrawal.

Perbandingan hasil pretest dan post-test dimaksudkan untuk mengetahui perbedaan tingkat kecenderungan kecanduan game online antara sebelum dan sesudah diberi treatment berupa konseling kelompok online pendekatan behavior teknik self management. Perbandingan hasil pre-test dan post-test tersebut dapat dilihat pada tabel 1.

Dari data tersebut dapat diketahui bahwa kecenderungan kecanduan game online siswa kelas XI di SMA Kesatrian 1 Semarang mengalami penurunan, baik secara individu maupun kenaikan rata-rata secara keseluruhan. Skor rata-rata gejala kecanduan game online siswa sebelum diberi konseling kelompok yaitu sebesar 3,7 dengan SD 1,1; kemudian setelah diberi konseling kelompok skor bertambah menjadi sebesar 2,3 dengan SD sebesar 0,9. Perubahan atau penurunan skor rata-rata tersebut sebesar 1,4 dengan SD 0,1 . Skor rata-rata awal sebelum mendapatkan termasuk dalam kategori kecenderungan kecanduan game online tinggi, kemudian setelah diberikan teratment kategori kecenderungan kecanduan game online siswa berubah menjadi kategori rendah.

Selanjutnya berdasarkan hasil uji Wilcoxon untuk mengetahui keefektifan pemberian konseling kelompok online pendekatan behavior teknik self management untuk mengurangi kecenderungan kecanduan game online siswa. Berikut merupakan hasil uji Wilcoxon:

Tabel 3. Hasil Uji Wilcoxon

\begin{tabular}{|c|c|c|c|c|c|c|}
\hline \multirow{2}{*}{$\mathbf{N}$} & \multicolumn{2}{|c|}{$\mathbf{T}_{1}$} & \multicolumn{2}{|c|}{$\mathbf{T}_{2}$} & \multirow{2}{*}{$\mathbf{Z}$} & \multirow{2}{*}{$\mathbf{p}$} \\
\hline & $\mathbf{M}$ & SD & $\mathbf{M}$ & SD & & \\
\hline 6 & 3,7 & 0,2 & 2,3 & 0,3 & $-2,201$ & 0,028 \\
\hline
\end{tabular}

Berdasarkan hasil uji Wilcoxon tersebut, diperoleh nilai $\mathrm{Z}$ hitung -2,201, dan asymp signifikansi 0,028 lebih kecil dari $\mathrm{p}$ tabel $0.05(\mathrm{z}=-2,201, \mathrm{p}<0.05)$. Dengan demikian dapat diartikan bahwa konseling kelompok online pendekatan behavior teknik self management efektif untuk mengurangi kecenderungan kecanduan game online pada siswa kelas XI di SMA Kesatrian 1 Semarang.

Kecanduan game online dapat diartikan sebagai penggunaan game online yang berlebihan (impulsif) yang ditandai dengan gangguan kognitif, emosional dan perilaku termasuk kehilangan kendali atas game, toleransi terhadap waktu, dan penarikan diri dari lingkungan (Griffiths dkk dalam Afriwilda, Wibowo, \& Mulawarman (2020). Game online banyak dimainkan secara berlebihan dan digunakan sebagai tempat untuk 
melarikan diri dari realitas kehidupan sehingga yang terjadi adalah kecanduan game online (Hussain \& Griffiths, 2009).

Gejala kecenderungan kecanduan game online merupakan perilaku dimana seseorang mengalami keinginan lebih atau ketergantungan terhadap game online. Berdasarkan aspek-aspek seseorang yang mengalami kecanduan game online yang meliputi (1) salience, (2) tolerance, (3) mood modification, (4) relapse, (5) withdrawal, (6) conflict, dan (7) problems, diketahui hasil analisis penelitian tingkat gejala kecenderungan kecanduan game online pada keenam siswa sebelum diberikan menunjukkan dengan nilai rata-rata tinggi. Indikator yang menunjukkan kategori paling tinggi adalah salience dan withdrawal. Penelitian Consetta (2015), menjelaskan bahwa remaja menghabiskan waktu lebih banyak didepan smartphone dan internet selain untuk berkomunikasi, mereka juga merasa bebas dari kecemasan dan ketakutan, dan juga para remaja memanfaatkan smartphone sebagai sarana untuk melarikan diri dari dunia nyata, ketika siswa kesulitan beradaptasi di lingkungan sekolah atau masyarakat dan mereka diterima di dunia maya, maka mereka cenderung suka melarikan diri dari lingkungan sekitar.

Berdasarkan hasil analisis tersebut, dari keenam anggota konseling kelompok online pendekatan behavior teknik self management, seluruh anggota berjenis kelamin laki-laki. Hal ini sesuai dengan hasil penelitan yang dilakuan Jiang (2014) bahwa laki-laki menunjukkan tingkat kecanduan internet dan penggunaan game online yang lebih tinggi daripada perempuan. Andriani, Sriati, \& Yamin (2019) menyatakan bahwa laki-laki cenderung mengalami kecanduan karena memiliki kontrol diri yang lebih rendah dibandingkan perempuan sehingga mudah untuk terkena adiksi. Bahkan, kontrol diri yang rendah akan mempengaruhi durasi seseorang dalam menggunakan game online sehingga dapat menjadi kecanduan.

Layanan konseling kelompok digunakan sebagai treatment untuk meningkatkan kedisiplinan siswa dikarenakan konseling kelompok dapat memenuhi kebutuhan psikologis individu. Sesuai dengan pendapat Mashudi (2014) menyatakan bahwa konseling kelompok adalah layanan yang membantu peserta didik dalam pembahasan dan pengentasan masalah pribadi melalui dinamika kelompok. Layanan konseling secara online adalah salah satu strategi layanan konseling yang bersifat virtual atau konseling yang berlangsung melalui bantuan koneksi internet (Bloom, 2004). Dengan memberikan konseling kelompok online kepada anggota kelompok diharapkan dapat memberikan layanan profesional untuk membantu mengentaskan masalah tersebut dengan segera namun dengan kemudahan dalam hal fleksibilitas waktu dan tempat dan mengedepankan adanya dinamika kelompok.

Pendekatan behavior diberikan pada siswa selama pemberian konseling, karena terapi behavior diarahkan pada tujuan untuk memperoleh tingkah laku baru dan penghapusan tingkah laku yang maladaptif (Corey, 2005). Salah satu teknik dalam pendekatan behavioral yang dapat digunakan dalam mengatasi kecanduan game online siswa adalah teknik self management (Erdiyati, 2018). Pelaksanaan teknik self management digunakan agar anggota kelompok dapat melakukan perencanaan, pemusatan perhatian, dan evaluasi terhadap aktivitas yang dilakukan untuk mengurangi kecenderungan kecanduan game online. Di dalam teknik self management terdapat kekuatan psikologis yang memberi arah pada individu untuk mengambil keputusan dan menentukan pilihannya serta menetapkan cara-cara yang efektif dalam mencapai tujuannya (Suwanto, 2016). Keenam siswa di bimbing untuk dapat melakukan berbagai rencana perilaku baru yang lebih baik berkaitan dengan gejala kecenderungan kecanduan 
game online yang mereka miliki, dan mempraktikkannya dalam kehidupannya supaya dapat berkurang. Pada sesi akhir konseling mereka melakukan analisis dan evaluasi tehadap perilaku baru mereka, sehingga jika berhasil maka dapat dipertahankan.

Setelah diberikan perlakuan berupa konseling kelompok online pendekatan behavior teknik self management tingkat kecenderungan kecanduan game online mengalami penurunan, semula dari kategori tinggi kemudian menjadi kategori rendah. Keenam siswa mengalami perubahan yang cukup baik. Hal ini sesuai dengan penelitian Lestary \& Winingsih (2020) menunjukkan juga kesesuaian dengan hasil penelitian ini bahwa pelaksanaan konseling kelompok dengan strategi self management dalam pendekatan behavior efektif digunakan untuk mengurangi kecanduan siswa. Selain itu, siswa mendapatkan pemahaman baru

Berdasarkan dari hasil analisis deskriptif, hasil observasi langsung saat pelaksanaan treatment, dan dari hasil analisis uji wilcoxon semuanya menunjukan adanya perubahan positif pada siswa kelas XI SMA Kesatrian 1 Semarang. Perubahan positif tersebut yaitu penurunan gejala-gejala kecenderungan kecanduan game online siswa yang menjadi anggota kelompok setelah mendapatkan treatment berupa konseling kelompok online pendekatan behavior teknik self management.Sehingga dapat disimpulkan bahwa konseling kelompok online pendekatan behavior teknik self management efektif untuk mengurangi kecenderungan kecanduan game online siswa.

\section{PENUTUP}

Berdasarkan hasil penelitian dapat disimpulkan bahwa konseling kelompok online pendekatan behavior teknik self management terbukti efektif untuk mengurangi kecenderungan kecanduan game online pada siswa kelas XI di SMA Kesatrian 1 Semarang. Walaupun penelitian ini mampu membuktikan bahwa konseling kelompok online pendekatan behavior teknik self management efektif untuk mengurangi kecenderungan kecanduan game online, namun keterbatasan dalam penelitian ini yaitu pada metode penelitian, serta jumlah subyek penelitian yang dirasa sedikit. Rekomendasi untuk penelitian selanjutnya diharapkan dapat menggunakan metode penelitian lain yang lebih kompleks, sehingga dapat memperbanyak jumlah siswa penerima layanan konseling kelompok. Selain itu agar sekolah dapat memberikan layanan konseling kelompok online pendekatan behavior teknik self management pada siswa yang memiliki kecenderungan kecanduan game online tinggi.

\section{DAFTAR PUSTAKA}

Amani, Nasanin (2007). Investigating The Nature, The Prevalence, And Effectiveness Of Online Counseling, A Thesis, Department of Educational Psychology, Administration and Counseling, California State university Long Beach.

Andriani, W. S., Sriati, A., \& Yamin, A. (2019). Gambaran Kontrol Diri Penggunaan Smartphone Pada Siswa Sekolah Menengah Atas Dan Sederajat Di Kecamatan Jatinangor. Jurnal Keperawatan Komprehensif, 5(2), 107-117. https://doi.org/10.33755/jkk.v5i2.143

Ardani, W. A., Erwin, A., \& Halik, A. (2019). Efektivitas Konseling Kelompok Dengan Teknik Self Management Untuk Mereduksi Perilaku Membolos. Guidance Jurnal Bimbingan Dan Konseling, 16(01), 7-14.

Ariantoro, T. R. (2016). Dampak Game Online Terhadap Prestasi Belajar Pelajar. JUTIM, $1(1), 45-50$. 
Concetta de Pasquale, Federica.S, \& Zira Hichy. 2015. Smartphone Addiction and Dissociative Experience: An invertigation in Italian adolescents aged between 14 and 19 years. Psychology \& Behavior Analysis. Vol.1 No 2. 109.

Erdiyati. (2018). Konseling kelompok dengan pendekatan behaviouristik untuk siswa SMP. Jurnal Prakarsa Paedagogia, 1(1), 61-66.

Gaol, T. L. (2012). Hubungan Kecanduan Game Online Dengan Prestasi Mahasiswa Fakultas Teknik Universitas Indonesia. Fakultas Ilmu Keperawatan UI, 47.

Granic, I., Lobel, A., \& Engels, R. C. M. E. (2014). The benefits of playing video games. American Psychologist, 69(1), 66-78. https://doi.org/10.1037/a0034857

Habsy, B. A. (2017). Model Konseling Kelompok Cognitive Behavior Untuk Meningkatkan Self Esteem Siswa SMK. Perspektif, 31(1), 21-35. Retrieved from http://journal.unj.ac.id/unj/index.php/pip/article/view/2644

Isnaini, F., \& Taufik. (2015). Strategi self-management untuk meningkatkan kedisiplinan belajar. Jurnal Penelitian Humaniora, 16(2), 33-42.

Jiang, Q. (2014). Internet addiction among young people in China: Internet connectedness, online gaming, and academic performance decrement. Internet Research, 24(1), 220. https://doi.org/10.1108/IntR-01-2013-0004

Kartini, H. (2016). Hubungan Antara Konformitas Teman Sebaya dan Intensitas Bermain Game Online dengan Intensi Berperilaku Agresif Pada Siswa SMA Katolik W.R Soepratman Samarinda. Psikoborneo, 4(4), 482-489.

Komalasari, Gantina, Wahyuni dan Karsih. 2011. Teori dan Teknik Konseling.Jakarta: PT. Indeks

Kusumawardani, S. P. (2015). Game Online Sebagai Pola Perilaku (Studi Deskriptif Tentang Interaksi Sosial Gamers Clash Of Clans Pada Clan Indo Spirit). Jurnal Antropologi FISIP Universitas Airlangga, 4(2), 154-163. https://doi.org/10.1145/1137677.1137679

Lemmens, J. S., Valkenburg, P. M., \& Peter, J. (2009). Development and validation of a game addiction scale for adolescents. Media Psychology, 12(1), 77-95. https://doi.org/10.1080/15213260802669458

Lestary, Y. D., \& Winingsih, E. (2020). MENGURANGI KECANDUAN MEDIA SOSIAL SISWA DI SMAN 1 DRIYOREJO. Jurnal BK Unesa, 11(3), 288-294.

Mashudi ,Farid. 2012. Psikologi Konseling. Jogjakarta: IRCiSoD

Peckham, Eric. 2020. Despite pandemic, gaming is well-positioned to withstand recession. Techcrunch [Internet]. [Diunduh pada 15 Desember 2019]. https://techcrunch.com/2020/03/30/despite-pandemic-gaming-is-well-positionedto-withstand-recession/

Suwanto, I. (2016). Self Management Untuk Membantu. Jurnal Bimbingan Konseling Indonesia, 1(1), 1-5. 